\title{
CEPAL
}

Review

Executive Secretary of ECLAC

Gert Rosenthal

Deputy Executive Secretary for Economic and Social Development

Andrés Bianchi

Deputy Executive Secretary for Co-operation and Support Services

Robert T. Brown

\section{Director of the Review}

Aníbal Pinto

Technical Secretary

Eugenio Lahera

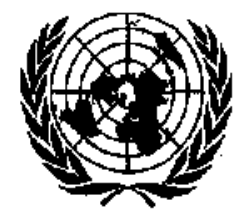

UNITED NATIONS

ECONOMIC COMMISSION FOR LATIN AMERICA AND THE CARIBBEAN

SANTIAGO, CHILE. APRIL 1988 


\section{E P A L}

\section{Review}

Santiago, Chile

Number 34

\section{CONTENTS}

An economic policy for development. Norberto Gonzälez.

An assessment of the structuralist paradigm for Latin American development and the prospects for its renovation. Osvaldo Rosales.

An outline of a neo-structuralist approach. Ricardo Ffrench-Davis.

Neo-liberalism versus neo-structuralism in Latin America. Sergio Bitar.

The challenges facing Latin America in the world today. Guillermo Maldonado Lince.

International primary commodity marketing and Latin America. Mikio Kwwayama.

Urban employment: research and policy in Latin America. Victor E. Tokman.

Small and medium-scale industry in the development of Latin America. Mario Castillo and Claudio Cortellese.

Prebisch's ideas on the world economy. Armando Di Filippo.

Prebisch: a classic and heterodox thinker. Benjamin Hopenhayn.

Raúl Prebisch central banker. Felipe Pazos.

Dependence, interdependence and development. Raúl Prebisch. 


\section{CEPAL REVIEW No. 34}

\section{Raúl Prebisch, central banker*}

\author{
Felipe Pazos**
}

This article covers a little-known period of Raúl Prebisch's life, when he was Chairman of the Central Bank of Argentina. In order to set the stage for the discussion that follows, the aurhor first provides background information concerning Argentina's economic policy, the creation of the Central Bank and the tasks assigned to it during the period in question.

Particular attention is devoted to the steps thar were taken to put the banks on a sounder footing and to streamline the banking system, as well as the banking law and the supervision of banks, the formation of a securities market, open-market and rediscounting operations and exchange policy. The effects of these policies during the upswing and downswing of the 1935-1939 economic cycle are examined, as are their relationship to the new conditions created by the Second World War.

Finally, the author takes a look at the lessons to be drawn from Prebisch's handling of monetary affairs with a view to their application to the present situation.

- Prepared for inclusion in a bosok in tribute to the memory of Alfredu Machado Gómez.

- Adviser to the Central Bank of Venezuela.

\section{Introduction}

Raúl Prebisch's achievements during the course of his international career are widely known by all economists, in Latin America and elsewhere, and by many Latin Americans outside the profession, but his work at the national level is virtually unknown, even by Spanish-speaking economists who specialize in monetary theory and policy. Nonetheless, the work he did during this phase in his life was just as extraordinary and productive as were his subsequent activities in the United Nations. When Raúl Prebisch was appointed as a consultant to the Economic Commission for Latin America in 1948, he was already 47 years of age and had a brilliant career to his credit, spanning the years from 1930 to 1943, first as an Under-Secretary of the Treasury and later as the General Manager of the Central Bank of the Argentine Republic. Between 1944 and 1948, Prebisch worked as a professional consultant and advised various governments and official agencies, including the Banco de México. It was there that in 1945 he held his talks on the central banking system that were to be published many years later, together with the annual reports for the years 1935-1943, by the Central Bank of the A rgentine Republic in two volumes which should be required reading for all students of monetary policy. ${ }^{1}$ During his time as a consultant, Prebisch's services were also contracted, in 1947 , by the Central Bank of Venezuela, to which he submitted a report that was later published in the Revista de Hacienda (Treasury Review) of Venezuela. ${ }^{2}$ In his report, Raúl Prebisch placed great emphasis on the need to regularize Venezuela's economic growth. To this end, he recommended the creation of a fund of 100 million bolivares, which at that time was equivalent to around $8 \%$ of fiscal revenues, for the purpose of offsetting cyclical fluctuations. These resources were to be provided by the Treasury, but the fund was to administered by the Central Bank. In 1949 Prebisch began to work as an adviser to the Economic Commission for Latin America,

'Central Bank of the Argentine Republic, Lu creación det Banco Central y la experiencia monetarial argentina entro tos atos 1935-1973, Buenos Aires, 1972.

${ }^{2}$ Raúl Prebisch, Dictamen acerca de los anteproyectos subre Banco Central y Bancos, Ret'istu de Huciends, Caracas, September 1948 . 
where he launched his international career with the writing of his famous treatise on the deterioration of the terms of trade. He later became the Executive Secretary of the Commission itself, of UNCTAD and of ILPES and served as an adviser to the Secretary-General of the United Nations. In this article, however, I will speak only of his career in the Central Bank.

\section{Background}

I first heard Raúl Prebisch's name in April or May 1945 from Robert Triffin, who referred to him as one of the best economists he had ever met. Since Robert Triffin knew all the great economists of the period, I thought he was exaggerating, but I later came to see that this was not so. In any event, the fact that $I$ heard Prebisch's name for the first time 11 years after I had begun studying economics and five years after I had written a book on monetary issues testifies to the lack of communication among Latin American economists at that time and, of course, does not speak well of the comprehensiveness of my scholarship either. In my own defense, however, I should point out that I did know that around 1940 the Central Bank of the Argentine Republic had applied a number of innovative anticyclical policies which had been praised on numerous occasions by the League of Nations in its Yearbooks on currency and banking. I was thus aware of Argentina's outstanding monetary policies, but I did not know the name of the person who had devised them, had pur them into practice and had explained their purpose and import in the terse and clear prose used in the annual reports of the Central Bank of the Argentine Republic.

A year and a half later, I met Prebisch in Mexico City at the First Conference of Central Bank Technical Experts of the Americas, which was held in September 1946. This was the beginning of a friendship that was to last for very nearly 40 years and which was ended only by his death in April 1986. As I have said on repeated occasions, my admiration for him was as great as that which any man can feel for another.

\section{The effectiveness of Argentina's economic policy from 1930 to 1943}

From 1930 to 1935 Raúl Prebisch served as Under-Secretary of the Treasury and as the chief economic adviser to the Government of Argentina. From 1935, the year in which the Central Bank was founded, to 1943 he was its General Manager, its head economisc and the person who formulated and determined its policies. Between 1930 and 1943 Argentina's economic policy was largely under his direction, and it is he who deserves the credit for its success. Argentina was one of the countries most severely affected by the Great Depression. As shown in table 1, the country's export earnings and capital inflows declined so sharply that by 1933 its imports had dropped to $42 \%$ of their 1929 level in real terms. However, the economic policy applied in the country succeeded in lessening the decrease in the real gross domestic product, which only fell to $86 \%$ of the record high it had reached in 1929. By 1939 the real domestic product was $15 \%$ greater than it had been ten years earlier. Argentina's policy was thus much more effective than that of the United States, where real income had fallen $31 \%$ in 1933 and had barely recovered by 1939, when its real level was just $1.3 \%$ higher than before the depression.

Table !

ARGENTINA: ECONOMIC TRENDS, $1929 \cdot 1943$

$(1929=100)$

\begin{tabular}{|c|c|c|c|c|c|}
\hline & 1929 & 1933 & 1935 & 1939 & 1943 \\
\hline Exports & 100.0 & 51.7 & 72.4 & 72.6 & 101.3 \\
\hline Imports & 100.0 & 42.2 & 60.4 & 74.0 & 47.2 \\
\hline Industrial & & & & & \\
\hline $\begin{array}{l}\text { output } \\
\text { GDP in real }\end{array}$ & 100.0 & 101.9 & 116.9 & 153.8 & 176.4 \\
\hline terms & 100.0 & 85,6 & 88.7 & 114.7 & 153.6 \\
\hline $\begin{array}{l}\text { Cost of living } \\
\text { Wholesale }\end{array}$ & 100.0 & 78.6 & 82.1 & 92.9 & 103.6 \\
\hline prices & 100.0 & 89.6 & 100.4 & 112.5 & 201.2 \\
\hline
\end{tabular}


Between 1932 and 1939 Argentina's manufacturing industry grew at an average rate of $7.1 \%$ per year or, if the calculations are based on the peak level achieved in 1929, at an annual rate of $4.4 \%$, which was much higher than the $2.5 \%$ rate recorded in 1944-1955, the years that are generally considered to have been those of the greatest industrial progress in Argentina's modern history. In concluding this brief review of the Argentine economy during the Great Depression, it should be noted that in 1939 wholesale prices were only $12.5 \%$ higher than they had been in 1929, while the cost-of-living index stood at virtually the same level.

\section{The founding of the Central Bank}

During Raúl Prebisch's tenure as UnderSecretary of the Treasury, much of his time was devoted to the preparation of legislation providing for the creation of a central bank, an institution which did not exist in Argentina at that time. In its stead, there were two agencies which, berween them, performed its functions in a nor entirely satisfactory fashion: the Conversion Fund, which issued the local currency in exchange for foreign currency and which, on an exceptional basis, was authorized to buy government securities; and the Banco de la Nación Argentina, which was the depository and fiscal agent of the Government and which on exceptional occasions made loans to other banks. In addition, the Exchange Control Office had been established at the start of the Great Depression, and this agency also carried out activities which were closely related to central banking functions. Nonetheless, it was generally agreed that this system did not work well and, in spite of the fear that the creation of a central bank would cause inflation, the establishment of such an institution was felt to be necessary.

In 1932 Raúl Prebisch was the most active member of a commission that had been organized to prepare legislation for the purpose of creating a central bank. The commission was apparently unable to complete its work because a new Minister of the Treasury decided to entrust the task to a foreign expert. He asked the Bank of England to make available the services of Sir Otto Niemeyer, who drafted a bill which was sent to Congress, after it had been modified and supplemented by Argentine experts, the most notable among them being Raúl Prebisch, who, once the law was passed, was appointed as the first General Manager of the institution. I am convinced that the provisions in this law that made the Bank so extraordinarily effective, as well as the supporting institutions which contributed to its success, were the work of Prebisch.

In the talks he gave at the Banco de México in 1944 on Argentina's experience with monetary affairs (which, as I said earlier, should be required reading in alt university classes on monetary and banking matters), Raúl Prebisch was too much of a gentleman to claim credit for the modifications made in Niemeyer's draft legislation, but this fact nonetheless comes across implicitly in his narration of the process, in words that deserve to be quoted both because of the light they shed on the paternity of this legislation and because they demonstrate the extraordinary foresight with which it was prepared. Prebisch said:

"Mr. Hueyo, the Minister of the Treasury, who had been a member of the Commission which drafted the plans for the Central Bank during Uriburu's tenure as Minister, abandoned the idea of revaluing gold and confined his efforts to drafting a banking law and some reforms to the Law on Rediscounting aimed at providing funds to banks with locked-up capital. At the same time he requested the advisory services of Sir Otto Niemeyer of the Bank of England, who in early 1933 prepared draf legislation for the creation of a central bank and for a law on banks. In 1934 Dr. Pinedo arrived at the Ministry and undertook the reform of the monetary and banking system. The draft legislation he sent to Congress conformed to the structure and technical provisions of the bills prepared by Sir Otto Niemeyer but differed radically from them as regards the concept of bank policy which it embodied in relation to both the present banking situation and the future course of this policy. Let us see exactly what these differences were:

"In so far as the banking system was concerned, Niemeyer's draft legislation did not propose any steps aimed at putting the banks on a sounder fooring. In contrast, the new bills provided for the creation of the Mobilization Institute for this purpose using funds obtained from the revaluation of gold, as discussed earlier. The 
financial rehabilitation of the banking system was regarded as essential in order for the Central Bank to be able to commence its operations without hindrance or distraction. In addition, whereas the new legislation also relied on the revaluation in order to pay the floating debt, Niemeyer's draft proposed that 130 million pesos in Treasury funds be used for its amortization along with a portion of the Central Bank's profits.

"The main differences with respect to Central Bank policy were the following:

"Firstly: The new legislation provided for the creation of the Bank Inspection Office as an organ of the Central Bank and gave it broad powers for examining the standing of credit institutions. The bills drafted by Niemeyer, however, would have required only that the banks submit financial statements to the Central Bank.

"Secondly: The new legislation gave the Central Bank a means of absorbing excess funds in the market so that it might influence the cyclical process. Niemeyer's legislation made no reference whatsoever to any instrument of this sort.

"Thirdly: Whereas under Niemeyer's legislation the Central Bank's holdings of foreign exchange would not have been subject to any limitation whatsoever, the government's new draft legislation stipulated that the Central Bank could have no more than $20 \%$ of its total holdings of gold and foreign exchange in the form of foreign exchange, while the rest would have to be held encirely in precious metals; furthermore, only one-half of this $20 \%$ in foreign exchange could be counted in the calculation of the Central Bank's legal reserves.

"Fourthly: Under Niemeyer's bill, the Central Bank's discount rate could be raised if the level of monetary reserves fell to less than $33 \%$ of cash holdings. The government's new legislation eliminated this restriction, which would undoubtedly have had had serious repercussions on the overall economic situation if it had been applied during a cyclical downturn at a time when gold was being exported.

"Fifthly: While the government's new legislation, bearing in mind the nature of the portfolios and operating procedures of Argentine banks, allowed for the discounting of unsecured paper, i,e., paper having a single signature, plus the signature of the discounting bank, Niemeyer's draft called for two signatures in addition to that of the bank and eliminated industrial discount paper.

"The above comparison clearly shows that Argentina's Central Bank Law represents an adaptation of Niemeyer's draft to the Argentine context which modified it so as to bring it into line with the actual circumstances in Argentina,"

As may be seen, the Mobilization Institute, the Central Bank's banking inspection unit, and the authorization of the sale and repurchase of consolidated treasury bonds, i.e., the original aspects of this law and the instruments which allowed the Central Bank to perform its work so well during its first eight years, were the creations of Prebisch.

\section{The economic situation at the time of the creation of the Central Bank and the tasks it faced}

In 1935 when the Central Bank began its operations, Argentina had, for the most part, come out of the 1929-1930 crisis thanks to the government's industrialization policy and to the partial recovery of the external market. By that year, the government had balanced its current income and expenditure as a result of its reduction of public spending, the institution of tax reforms and the greater receipts made possible by the expansion of the national product. The balance of payments was also once again at equilibrium, and the exchange system had been stabilized with the operation of a dual exchange system in which the free rate fluctuated around a level only slightly higher than the official exchange rate.

All of these advances, which pre-dated the creation of the Central Bank, had in large part been made possible by the work of the man who was to become the Bank's first General Manager. As Under-Secretary of the Treasury and chief economic adviser to the government, Raúl Prebisch had played a decisive role in the adoption of a moderate policy of tariff prorection which had promoted the creation of new indus-

Central Bank of the Argentine Republic, op. cit., p. 267. 
tries, in the reduction of public spending, the establishment of an income tax, and the organization of the dual exchange system whereby the free exchange rate rose enough to discourage capital outflows but not so much as to produce economic distortions.

These successes notwithstanding, a considerable part of bank portfolios remained immobilized, and no public securities market, either short- or long-term, had yer been developed; such a market was needed so that a portion of savings could be channelled towards public investment and so that open-market operations could be conducted for the purpose of absorbing excess liquidity during economic booms and feeding it back into the economy during downturns. The immobility of bank portfolios had been caused by the excessively open-handed credit policy followed by the banks during the pre-crisis period, by the decrease in the prices of agricultural export products and in farmers incomes, and by the saturation of government paper. The absence of a public securities market, for its part, was to some extent a natural consequence of the country's stage of economic development. A much more significant factor, however, was the imbalance in public finances which had existed until one or two years before, inasmuch as Argentina was already generating enough savings so that a portion of these funds might be channelled to the purchase of securities issued by the public sector.

By virtue of its very creation, the new institution brought under one roof the central banking functions which had previously been scattered among the Conversion Fund, the Banco de la Nación Argentina and the Exchange Control Office, thereby making it possible to conduct these operations more efficiently. In addition to its routine functions, however, the new institution was confronted with the following rasks: a) to put the banking system on a sound footing, b) to create a public securities market, and c) to use this market, in conjunction with the exchange system, in order to apply an anticyclical policy aimed at preparing the country for the slump in external inflows which was expected to occur within the next two or three years. As will be discussed below, the Central Bank accomplished these tasks fully and extremely efficiently.

\section{Putting the banking system \\ on a sound footing and \\ freeing its assets}

The position of the banking system was improved and the banks' assets were freed for use by means of the revaluation of gold reserves at the time they were transferred from the Conversion Fund to the Central Bank and the allocation of the resulting profits to the creation of a new body, the Bank Investment Mobilization Institute, which bought up the banks' public securities and the overdue private loans they had in their portfolios. The the Mobilization Institute was thus created in a thoroughly heterodox manner which was potentially extremely inflarionary. Instead of sparking a rapid price and wage spiral, however, this measure had highly positive effects: it served to unblock bank portfolios, made possible the establishment of a public securities market and gave the Central Bank the ability to carry out transactions on the open market.

The value of the Conversion Fund's gold reserves had been set in the 1920s, before the devaluation of the pound sterling and the dollar and before the depreciation of the Argentine peso in relation to these currencies; hence, the revaluation of these gold reserves nearly doubled their value and rendered an accounting profit of 701.1 million pesos, which was equivalent to one and one-half times the value of the cash reserves ( 485.3 million pesos), maintained by the banks prior to the freeing of their assets. The use of this sum to purchase blocked assets more than doubled cash reserves and could have led to a huge increase in bank credit; this increase did not actually occur, however, because the Central Bank reabsorbed one-third of the growth in cash reserves through the sale of securities and persuaded the banks to refrain from expanding their lending activity. The Central Bank's power of persuasion was reinforced by the fact that, as shown in table 2, cash reserves had fallen to such extremely low levels that even this enormous increase only raised them to a level just slightly higher than those recorded in the three-year period from 1926 to 1928 . In addition, yet another factor was that the troubles experienced by the banks during the years that their assets had been tied up caused them to adopt a much more conservative attitude. 
Between December 1934 and December 1935 bank reserves rose from $14.0 \%$ to $24.7 \%$ of their deposits; however, loans increased by just $1.7 \%$, the money supply expanded by less than $10 \%$ and the cost of living climbed only. $4.5 \%$ (see table 3). Wholesale prices dropped 1.0\% and the price of the pound sterling on the free market went down from 19.48 to 18.09 . The financial "explosion" which some had feared did not occur. In creating the Bank Investment Mobilization Institute, Raúl Prebisch was playing with dynamite, but he knew how to keep it from going off!

\section{The Bank Law and banking inspection}

Together with the laws that created the Central Bank and the Mobilization Institute, Congress passed a General Bank Law which prohibited banks of deposit from making long-term loans and from owning real estate or corporate stock. These operations had been permitted up until that time and they had been part of the reason why the banks' portfolios had become immobilized. With a view to enforcing these regulations and monitoring bank operations, the Central Bank Law provided that this institution should form an inspection department.

The General Bank Law was an orthodox law which conformed to the standard provisions contained in the legislation on this subject. The

Table 2

\section{ARGENTINA: BANK DEPOSITS AND RESERVES, 1926-1935}

(Year-end balances in millions of Argentine pesos)

\begin{tabular}{lccc}
\hline & Deposits & $\begin{array}{c}\text { Cash } \\
\text { holdings }\end{array}$ & $\begin{array}{c}\text { Reserves } \\
\text { (percentage) }\end{array}$ \\
\cline { 2 - 4 } 1926 & 3347 & 618 & 18.5 \\
1927 & 3477 & 635 & 18.3 \\
1928 & 3836 & 909 & 23.7 \\
1929 & 3986 & 705 & 17.7 \\
1930 & 3913 & 528 & 13.5 \\
1931 & 3731 & 484 & 13.0 \\
1932 & 3536 & 596 & 16.9 \\
1933 & 3514 & 609 & 17.3 \\
1934 & 3465 & 485 & 14.0 \\
1935 & 3357 & 827 & 24.7 \\
\hline
\end{tabular}

Source: Central Bank of the Argentine Republic, annual repurt for 1935.
Table 3

ARGENTINA: COMPARATIVE FIGURES, 1934-1935

\begin{tabular}{lccc}
\hline & $\begin{array}{c}\text { December } \\
1934\end{array}$ & $\begin{array}{c}\text { December } \\
1935\end{array}$ & $\begin{array}{c}\text { Difference } \\
\text { (percentage) }\end{array}$ \\
\cline { 2 - 4 } Cash holdings & 485 & 827 & 70.5 \\
Deposits & 3465 & 3357 & -3.1 \\
Reserves & 14.0 & 24.7 & 76.4 \\
Loans & $2821^{*}$ & 2870 & 1.7 \\
Money supply & 2010 & 2190 & 9.0 \\
Cost of living & 100.0 & 104.5 & 4.5 \\
Wholesale prices & 100.0 & 99.0 & -1.0 \\
Pound sterling & 19.48 & 18.09 & -7.1 \\
\hline Source: Central Bank of the Argentine Republic, annual report for \\
1935 and the statistical supplement of August 1937. \\
'Total loans minus loans absorbed by the Mobilization Institute in \\
May 1935.
\end{tabular}

organization of a bank inspection system was, per se, also an orthodox step. However, the decision to make it a unit of the Central Bank was not at all orthodox, but was instead a complete departure from the customary practices of that period. In countries where the inspection of banks was practiced at that time, this function was performed by an independent agency, which generally reported to the Ministry of the 'Treasury. Raúl Prebisch understood, however, that such supervision would be much more effective if it were backed up by the economic pressure that the lender of last resort could exert. In addition, he took into account the fact that the inspectors could be paid higher salaries and enjoy greater stability if they were staff members of the Central Bank. This approach, which was an exceptional one in 1935, has come into more general use over time, as may be seen by the fact that in 14 out of 22 Latin American countries the corresponding Superintendency is now part of the Central Bank or Monetary Board.

\section{The formation of a securities market}

The main tool of monetary policy used by the Central Bank of the Argentine Republic during Prebisch's time was the purchase and sale of

\footnotetext{
${ }^{4}$ Centre for Latin American Monetary Studies (CEMLA), Informe sobre supertisión y fiscalizatión bancaria, Mexico City, 1982. p. 21.
} 
securities on the open market. This policy has also been the one most commonly employed by the central banks of financially developed countries since the late nineteenth century and especially since the end of the First World War. It is generally believed, as I myself thought until quite recently, that Prebisch had been able to imake use of this instrument because a securities market was already in existence in Argentina. As we have seen, however, this was nor so. The money market in Argentina was created at the same time that the Central Bank was established. Its formation was made possible, first of all, by the greater liquidity resulting from the revaluation of gold and from its use to unblock bank portfolios; an equally important factor, however, was the policy of empowering the Central Bank to issue and sell share certificates in the consolidated treasury bonds which the Bank had received from the Conversion Fund as part collateral for its monetary issue, since these certificates were easier to sell on the market due to their short term and the fact that they were backed by both the government and the Central Bank.

Before Argentina took this step, the experts on such issues thought that a central bank should not issue or sell bonds as a means of reducing the money supply because it could diminish the confidence of the public, which might think that the Central Bank was in need of resources. So strong was this belief that in 1941 the White Mission, which conducted the studies concerning the organization of the Banco Nacional de Cuba, recommended a complex mechanism for absorbing funds whereby bonds would be issued by the Currency Stabilization Fund, which was an account of the Central Bank rather than an institution as such.' Raúl Prebisch did not share this fear, and from the very start of its operations in May 1935, the Central Bank of the Argentine Republic issued and sold share certificates in consolidated treasury bonds. Nobody thought that these securities were issued because the Central Bank needed resources, and everyone felt confident about the creditworthiness of the

'These recommendarions were acted upon seven years later when the Banco Nacional de Cuba was created. However, this bank never issued bunds in either its own name or in that of the Currency Stabilization Fund. certificates, which met with immediate acceptance.

The most important factor of all in the creation of the securities market, however, was the enormous stock of money injected into the economy by the Mobilization Institute. This was what put the banks in a position to purchase share certificates in consolidated treasury bonds and, larer on, ocher Central Bank securities and treasury bills. The operations undertaken by the Institure in order to free up the bank's assers virtually doubled their reserves and provided them with more than enough funds to purchase securities from the Central Bank.

\section{Open-market operations}

In 1935 the Argentine economy was growing at an annual rate of $4.5 \%$ and was generating a gross domestic product equal to nearly $90.0 \%$ of its 1929 level. Neither the growth rate nor the degree of utilization of the production apparatus made it advisable to apply a monetary policy aimed at curbing the expansion, but the huge amount of liquidity that was fed into the economy in order to place the banking system on a sounder footing could have sparked a large increase in lending activity, in the means of payment, in aggregate demand, imports and prices. It was therefore necessary to absorb the excess liquidity. Accordingly, the Central Bank immediately initiated the issue and sale of share certificates in the consolidated treasury bonds it had in its portfolio. The certificates were issued for a 90-day term and with an annual yield of $2.75 \%$ and were offered in competitive bidding with a guarantee that they would be repurchased at the sale price. From the very beginning they were sold at a premium, which lowered their yield to $2.52 \%, 1.98 \%$ and $1.72 \%$ in December 1935,1936 and 1937, respectively.

Before the end of 1936, the Bank's a sales volume had reached 400 million pesos, which was equal to the amount of consolidated bonds it had in its portfolio; it therefore began to offer treasury bills (with the proceeds from these sales being used to retire public debts) and subsequently issued gold and foreign exchange certificates. By August 1937 it had sold 741 million 
Table 4

ARGENTINA: LIQUID ASSETS AND ABSORPTION, 1934-1938

(Millions of Argentine pesos)

\begin{tabular}{lccccccc}
\hline & \multicolumn{1}{c}{$\begin{array}{c}\text { Liquid } \\
\text { assets }\end{array}$} & $\begin{array}{c}\text { Absorption } \\
\text { by Central } \\
\text { Bank }\end{array}$ & $\begin{array}{c}\text { Cash } \\
\text { holdings }\end{array}$ & Deposits & $\begin{array}{c}\text { Percentage } \\
\text { of reserves }\end{array}$ & Loans \\
December & $\mathbf{1 9 3 4}$ & 485 & - & 485 & 3465 & 14.0 & 3424 \\
May & 1935 & 926 & - & 926 & 3338 & 27.7 & 2821 \\
December & 1935 & 1022 & 195 & 825 & 3357 & 24.7 & 2870 \\
June & 1936 & 1036 & 343 & 723 & 3510 & 20.6 & 2960 \\
December & 1936 & 1237 & 464 & 772 & 3668 & 21.0 & 3010 \\
July & 1937 & 1543 & 713 & 830 & 3915 & 21.2 & 3140 \\
December & 1937 & 1297 & 607 & 690 & 3881 & 17.8 & 3075 \\
June & 1938 & 1133 & 482 & 651 & 3829 & 17.0 & 3160 \\
December & 1938 & 1005 & 374 & 631 & 3790 & 16.6 & 3290 \\
\hline
\end{tabular}

Source: Central Bank of the Argentine Republic, annual reports and statistical supplements.

pesos worth of the three types of securities. ${ }^{6}$ However, as shown in table 4 , the banking system's liquid assets had begun to drop from their level of the month before, when they had reached a peak of 1543 million pesos. The Central Bank therefore moved swiftly to reduce its sales of securities, bringing them down to 373 million pesos in December 1938 and to progressively lower levels during the following years. In late 1941, the Central Bank was still issuing and selling certificates (in the amount of 30 million pesos), but its reason for doing so was probably co retain the use of a tool which it might need again in the future.

In the talks he gave at the Banco de México, Prebisch explained that the Central Bank authorities understood that it would have been much better to sell these securities to depositors rather than to the banks because this would have reduced both the public's purchasing power and the banks' lending capacity at one and the same time and because it would have been a more effective means of diminishing the banks' lending capacity, since it would then have been beyond the banks' power to recover this capacity

In addition co selling certificates and treasury bills, the Bank had bought 207 miltion pesos worth of dollars using resources from the Foreign Exchange Fund; this also involved a sterilization of funds. According to the figures available to the author, such sterilization operations amounted to a maximum of 948 million pesos. According to Nurkse, however, these operations totalled over 1 billion pesos as of June 1937. later merely by deciding to do so. The sale of short-term securities to banks allows the latter to regain their lending capacity upon the expiration of the securities simply by refraining from repurchasing them, something which they cannot do if the securities have been sold to the public; the banks' liquidity will nonetheless have been reduced because the public will have withdrawn money from its bank deposits in order to buy the securities. The Central Bank of the Argentine Republic was unable, however, to sell securities to the public because, in the case of share certificates, the law prohibited it from doing so and because, in the case of other securities, the banks opposed such a step on the grounds that the Central Bank should not compete with them in attracting the public's resources.

This is an extremely interesting aspect of Argentina's experience with monetary affairs because the argument that the Central Bank should not compere with other banks has been the major obstacle to the use of so important a policy tool as is the sale and purchase on the open market of securities issued by the Central Bank itself. The argument is not a valid one because the sale by a central bank of its own securities is not a form of competition but rather a means of monetary regulation which can be used as an alternative to raising bank reserve requirements. Nevertheless, this argument has been employed successfully to prevent the use of this instrument. 


\section{A policy of persuasion}

Even though it was brilliantly conceived and executed, the authorities' policy of absorbing excess funds could not have prevented a sharp increase in bank loans if it had not been for the Central Bank's effectiveness in persuading the banks to follow a prudent credit policy. Indeed, at no time did the sale of securities manage to bring down the banks' cash holdings to less than $21.0 \%$ of deposits, which was almost double the legal minimum reserve requirement. ${ }^{7}$ This made it possibie, as soon as their reserves increased for the banks to engage in such keen competition among themselves that they even took up the practice of visiting the clients of rival institutions in order to offer them credit at lower rates of interest. This was a cause of serious concern for the Central Bank authorities, not only for monetary reasons but also because their knowledge of the situation told them that this was not the right time to lower profits and enter into high-risk operations, since there were many severe financial problems that had yet to be resolved. The Central Bank called upon the banks to co-ordinate their policies and to reach an agreement among themselves by which they would pledge to refrain from lowering the interest rate to below $4 \%$. At first the banks resisted the idea, but the Central Bank persevered and the agreement was ultimately signed.

Along with its successful effort to curb any undue expansion of lending activity, the Central Bank made a recommendation to the banks (which they accepted) that they not pay dividends of over $5 \%$ so that they might build up their reserves. Thus, without the aid of any legal provision, but merely by means of its powers of persuasion, the Central Bank managed to convince the banks to use most of their profits to increase their capital.

\section{Rediscounting}

During Prebisch's tenure as General Manager, the Central Bank of the Argentine Republic

The law provided for a minimum reserve requirement of $16.0 \%$ on demand deposits and of $8.0 \%$ on time deposits. Since the former amounced to around one-third of the total and the latter to about two-thirds, the average minimum teserve requirement was between $10.0 \%$ and $11.0 \%$. refrained from carrying out rediscounting operations except during a brief period in 1940 , and even then the amounts involved were relatively smalt. In May of that year, the intensification of the fighting in the world war sent shock waves through the stock market and created a very uneasy situation for the banks, which feared a steep decline in foreign trade. The Central Bank intervened aggressively in the stock market. It bought up a considerable amount of securities, thereby stabilizing the market quotations, and asked the banks to "avoid placing restrictions on credit which might disturb the flow of business and cause unnecessary selling", telling them that "if, despite the banks' greatly improved cash position, they find it necessary to resort to the instrument which the law has made available to the Central Bank for facilitating banking operations, then the banks shall be permitted to discount as much of the eligible paper in their portfolios as they deem necessary". In response to this invitation, "major banks communicated their decision to carry out such rediscounting operations immediately, despite the abundance of liquid assets at their disposal, as an express means of showing their willingness to provide the marketplace with all the resources it might need".8 In June, the Central Bank carried out rediscounting operations totalling 79 million pesos (equivalent to around $10 \%$ of the banks' cash holdings at that time), with payment being made in full before the beginning of the following year.

In the talks he gave at the Banco de México, Prebisch did not speak about rediscounting until one of the final sessions, and then said that he had not mentioned it as an expansionary policy tool because "during the downswing of the cycle, private enterprises are not inclined to use more credit to expand their businesses since, generally speaking, the mood is one of reluctance rather than optimism".9 Prebisch did not speak of rediscounting as a tight-money policy either because, in its early days, the Central Bank of the Argentine Republic could not have made use of this tool due to the huge amount of excess liquidity created by the policy aimed at putting the banks on a sounder footing.

'Central Bank of the Argentine Republic, op. cis., P. 127. 'Central Bark of the Argentine Republic, op. cis., p. 499. 


\section{Advising the government}

During the first two years of its existence, the Bank does not seem to have exercised its function as an economic adviser to the government, at least not in regard to sufficiently important issues to warrant mention in the Bank's annual reports or in the talks given at the Banco de México; however, when the country entered into the next downturn of the economic cycle, the Central Bank then began to perform this function in a very thorough manner indeed. When exports slumped during the second half of 1937 and this decrease began to have an effect on domestic activity, the Bank recommended that steps be taken to counteract the slowdown. In this connection, Prebisch said the following: "Should the Central Bank help to reduce domestic economic activity so as to bring the balance of payments into a perfect state of equilibrium, or should it give priority to domestic economic activity and seek other means of influencing the balance of payments? This was the question we asked ourselves beginning in the second half of 1937 , and it was posed with increasing urgency as the cyclical downturn deepened. The Central Bank was quick to understand its domestic responsibility in the face of this economic situation, especially in view of the new fact of Argentine life represented by what had only in recent years become a hard-working industry. The tendency, then, was to protect domestic economic activity and to resort once again to exchange control measures in order to prevent the increased purchasing power created by the Banco de la Nación to aid farming activities (and which was later to spread to the other sectors of the economy) from going to imports and to ensure that it would instead continue to circulate within the local market." 10

In order to offset the slump, the Bank recommended that the government should tighten its exchange controls, which had become virtually negligible during the final stages of the upswing in the cycle. The Bank also supported the government's policy of purchasing harvest surpluses and played a decisive role in drafting an economic reactivation plan, whose rext reflected,

${ }^{10 B a n c o s}$ Central de la República Argentina, op. cit., p. 400. according to Carlos Díaz-Alejandro, "the unmistakable style of Raúl Prebisch"."1

\section{Exchange policy}

In 1931 the foreign exchange crisis and capital flight made it necessary for Argentina to establish exchange controls, initially under a rigid system providing for a single exchange rate and directed at regulating all transactions, and later under a differential exchange system that covered around $85 \%$ of all transactions, with the remaining $15 \%$ being allowed to take place on the free market. This system provided for three exchange rates: one of 15 pesos to the pound sterling for major exports, another of 16 pesos to the pound sterling for essential imports, and a floating rate for all other current transactions and capital movements. The Bank intervened actively in the free market in order to keep the exchange rate within a range of $17-20$ pesos to the pound sterling, i.e., a range of from $0.6 \%$ to $25.0 \%$ above the exchange rate for imports on the official market.

Without going into a detailed description of either the system or the modifications made in it in 1935-1943, it can be maintained that exchange controls were handled with extraordinary effectiveness in order to stimulate exports, curb imports, promote national industry and supplement the anti-cyclical effect of the country's domestic monetary policy. During periods when exports were on the rise, the inflow of foreign exchange pushed the free exchange rate down, lowering it to 17 , but at that point the Cencral Bank would start buying in order to prevent the rate from dropping below that level. When exports were declining, the exchange rate climbed, thereby helping to staunch the outflow of foreign exchange, but the Bank would then start selling and would thus keep the rate from going above 20.

During the period under examination, the free market in Argentina served to regulate both domestic and foreign capital movements and to hold down imports during cyclical downswings,

"Carlos F. Dlaz-Akjandro, Essays on the Economic History of the Argentine Republic, New Haven, Connecticut, Yale University Press, 1970, p. 105. 
and, since exchange rate fluctuations were kept within a narrow band, no price distortions were created and no appreciable incentive was provided for violating the controls. The moderate nature of these fluctuations was due to the Central Bank's policy of intervening in the market, but market expectations were the factor which made this policy's success possible. Throughout the period, domestic and foreign investors' faith in the Argentine economy remained unshaken; investors might feel that temporary capital transfers were advisable when the economy was undergoing transitory difficulties, but the tendency to withdraw capital slackened when the free exchange rate rose by $10 \%, 15 \%$ or, at the most, $25 \%$ since they felt confident that these difficulties would pass and the price of the pound and of the dollar would drop once again.

The talks he gave at the Banco de México demonstrate that Prebisch understood quite clearly that it did not make sense to place quan. titative restrictions on the imports of a product that would reduce the supply to below the existing level of demand while at the same time selling foreign exchange inexpensively to importers of that same product because the low price of the foreign exchange would benefir importers rather than consumers, inasmuch as such restrictions would push the product's sale price on the domestic market above the impors cost, thereby providing intermediaries with undue profits. In 1944 Prebisch had already grasped the significance of the Sohmen effect, thus called because it was first described by that author in 1958, even though Triffin had used the same concept many years before as the basis for his recommendation that the authorities lift the quantitative restrictions applying to imports in Ecuador in 1947.12

\section{The effects of the anti-cyclical policy}

In the preceding sections we have examined, one by one, the policies applied by the Central Bank of the Argentine Republic during the period

\footnotetext{
${ }^{12}$ Egon Sohmen, The effect of devaluation on the price system, Qwarterly Journal of Economics, May 1958. For Prebisch's explanation of this concept, see Central Bank of the Argentine Republic, op, cit., p. 308.
}

under examination (i.e., open-market transactions, rediscounting, the persuasion of the private sector and the provision of advisory services to the government). Now let us see what the effects of these policies were during the course of the period in question: first, in the cyclical upswing of 1935-1937, when they were used to counteract inflationary pressures; later, in the cyclical downswing of 1938-1939, when their use was aimed at preventing a slowdown in the real economy; and, finally, in the years 1940-1943, when the Bank was faced with the task of counteracting, supplementing and rectifying the serious distortions produced by the Second World War.

Strangely enough, the first policy implemented by the Cencral Bank was not an anticyclical measure, but rather a potentially pro-cyclical one. As we saw earlier, the first step taken by the Bank (through its auxiliary institution, the Mobilization Institute) was to improve the quality of the banks' portfolios by purchasing from them government securities and doubtful privace credits. This measure might have had explosive repercussions, but did not because its potentially inflationary effects were offset (or even more than offset) by the sale of securities and by the Central Bank's success in persuading the banks to follow its recommendations. In fact, the objective of the Central Bank's anti-cycical policy was not so much to counteract the expansionary effect of the increase in exports and in capital inflows as it was to sterilize the banks" excess liquidity. Fortunately, this policy prevented the improvement of the banks' portfolios from having an explosive impact and thereby made this a cost-free measure of enormous benefit to the nation.

The effectiveness of the Bank's anti-cyclical policies is clearly illustrated in figure 1 , which shows the trends observed in the means of payment and in gold and foreign-exchange reserves during the period in question, as well as the effect on the former of variations in the latter, with the residual representing the effect of changes in domestic credit. Figure 1 and table 5 have been taken, with slight adaptions, from the annual reports of the Central Bank, in which Raúl Prebisch first applied a technique of analysis that was later systematized and refined by Robert Triffin. This technique is used today, with a number of variations and refinements, by 
Figure 1

ARGENTINA: MEANS OF PAYMENT BY ORIGIN, 1935-1943

Millions of Argentine

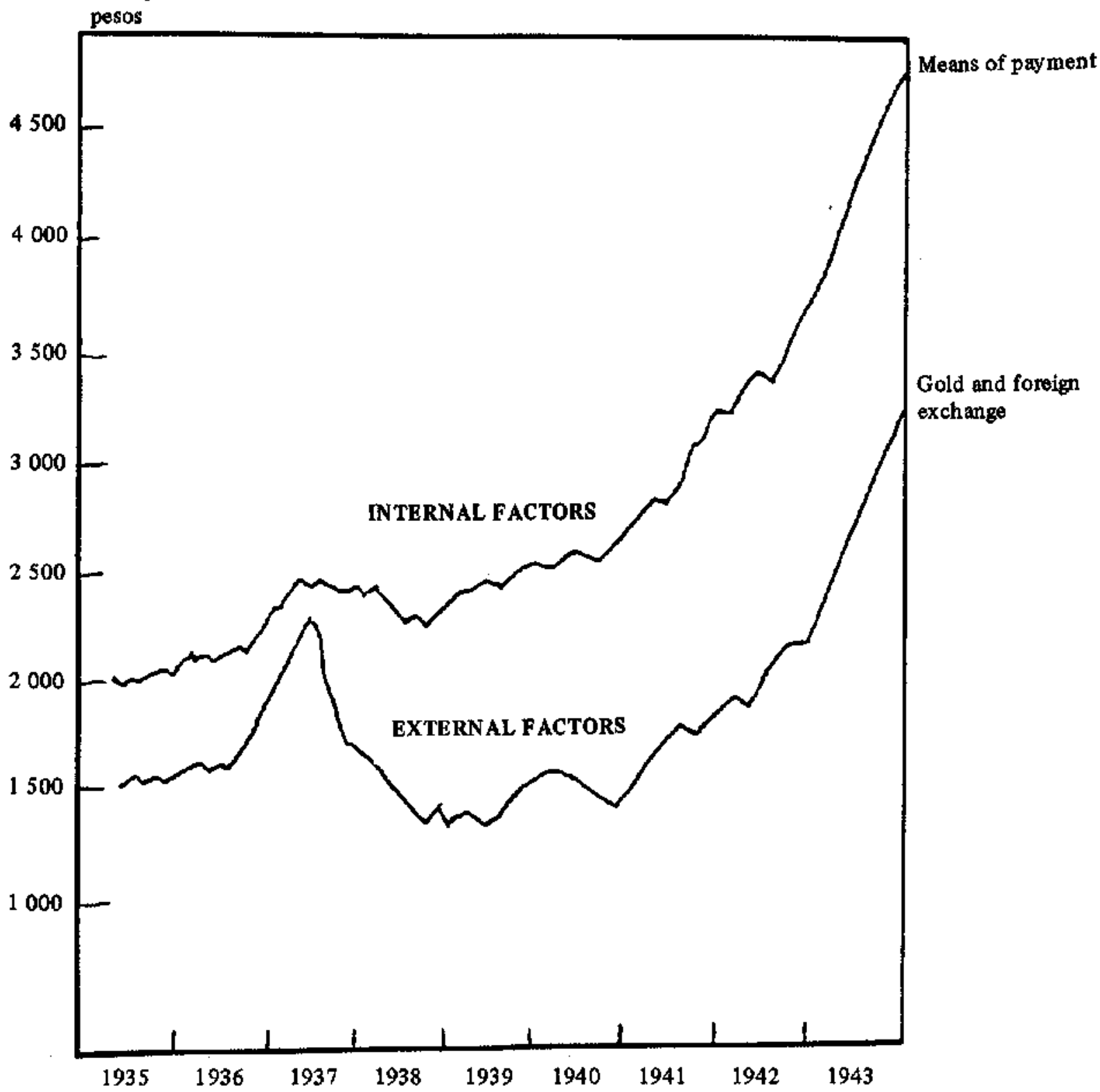

central banks and international monetary institutions. ${ }^{13}$

Figure 1 and table 5 show that the anticyclical policy entirely cancelled out the potential

1"Robert Triflin, Esbozo general de un análtisis de has series estadisticas monetarias y bancarias de América Latina sobre bases uniformes y comparables, First Conference of Central Bank Technical Experts of the Americas, Mexico City, 1946. impact of the increase in liquidicy generated by the unblocking of bank portfolios and largely offset the monetary effect of the growth of reserves resulting from the rise in exports. Between May 1935 and July 1937 the country's international reserves climbed by 840 million pesos, whereas the money supply rose by only 590 million pesos; this means that the sale of securities and the public's saving habits steril- 
Table 5

ARGENTINA: MEANS OF PAYMENT BY ORIGIN, 1935-1943

(Millions of Argentine pesor)

\begin{tabular}{|c|c|c|c|c|c|c|c|c|c|c|c|}
\hline & $\begin{array}{l}\text { May } \\
1935\end{array}$ & $\begin{array}{c}\text { De* } \\
\text { cember } \\
1935\end{array}$ & $\begin{array}{c}\text { De- } \\
\text { cember } \\
1936\end{array}$ & $\begin{array}{l}\text { Juty } \\
1937\end{array}$ & $\begin{array}{c}\text { De- } \\
\text { cember } \\
1937\end{array}$ & $\begin{array}{c}\text { De- } \\
\text { cember } \\
1938\end{array}$ & $\begin{array}{c}\text { De- } \\
\text { cember } \\
1939 \\
\end{array}$ & $\begin{array}{c}\text { De- } \\
\text { cember } \\
1940\end{array}$ & $\begin{array}{c}\text { De- } \\
\text { cember } \\
1941\end{array}$ & $\begin{array}{c}\text { De- } \\
\text { cember } \\
1942\end{array}$ & $\begin{array}{c}\text { De- } \\
\text { cember } \\
1943\end{array}$ \\
\hline $\begin{array}{l}\text { External } \\
\text { factors }^{a} \\
\text { Internal }\end{array}$ & 1460 & 1480 & 2000 & 2300 & 1700 & 1300 & 1480 & 1400 & 1870 & 2360 & 3650 \\
\hline $\begin{array}{l}\text { factors }^{b} \\
\text { Total }^{c}\end{array}$ & $\begin{array}{l}3210 \\
4670\end{array}$ & $\begin{array}{l}3250 \\
4730\end{array}$ & $\begin{array}{l}3300 \\
5300\end{array}$ & $\begin{array}{l}3280 \\
5580\end{array}$ & $\begin{array}{l}3470 \\
5120\end{array}$ & $\begin{array}{l}3620 \\
4920\end{array}$ & $\begin{array}{l}3840 \\
5320\end{array}$ & $\begin{array}{l}3850 \\
5250\end{array}$ & $\begin{array}{l}4650 \\
6420\end{array}$ & $\begin{array}{l}4980 \\
7280\end{array}$ & $\begin{array}{l}4960 \\
8610\end{array}$ \\
\hline $\begin{array}{l}\text { Less } \\
\text { absorption }{ }^{d} \\
\text { Money supply }\end{array}$ & 2670 & 2540 & 2900 & 2990 & 2450 & 2420 & 2560 & 2430 & 2860 & 2990 & 3350 \\
\hline$\left(\mathbf{M}_{2}\right)^{e}$ & 2000 & 2190 & 2400 & 2590 & 2670 & 2500 & 2760 & 2820 & 3560 & 4310 & 5760 \\
\hline
\end{tabular}

Source: Central Bank of the Argentine Republic; annual reports.

"Internacional reserves in gold and foreign exchange.

bloans and investments of the banking system.

'Sum of the above two quantities. The total is equivalent to muney plus quasi-money $\left(\mathrm{M}_{2}\right)$

${ }^{d}$ Savings and time deposits, other term obligations of banks and absorption of funds by the Foreign Exchange Fund.

Currency outside banks plis dẹmand depusics.

ized 250 million pesos of the potential expansion of the money supply. These results are truly astounding, even for those of us who already have a boundless admiration for the work of Prebisch.

In July 1937 exports began to drop and continued to do so until late 1938. This decrease in exports, which reduced their value by around $40 \%$ in the space of one and one-half years, affected domestic economic activity and resulted in a decline in reserves. Faced with this situation, the Bank recommended that the government tighten its exchange controls and require licenses for those imports which had been entering the country without them through the free market. At the same time, the Bank started to repurchase the securities it had sold during the upswing of the economic cycle, thus permitting the banks to maintain and even slightly increase their lending volumes. The economic slowdown also led to a reduction in time deposits, and the spontaneous absorption of the money supply by the public therefore diminished. Between July 1937 and December 1938 the money supply declined by only $6.8 \%$ despite the fact that international reserves were drawn down by $43.5 \%$. The following year, export values regained some of the lost ground and the money supply increased by approximately the same amount as did international reserves. In 1938 the gross domestic product shrank $2.8 \%$, but in 1939 it recovered, growing by $4.5 \%$.

In May 1940 the intensification of the war had the effect of shurting down the market for Argentine products in the European continent, shifting import trade towards the United States, and creating an imbalance between the inflows and outflows of foreign exchange, with the result that there was an abundant supply of pounds sterling and a serious shortage of dollars. This made it necessary for Argentina to establish controis which discriminated against imports from the United States. Later on, the United States' purchases of Argentine products increased sharply, but its sales remained very low due to war shortages. As a result, Argentina's reserves in gold and foreign exchange soared. Between 1940 and 1943 its reserves grew at an average annual rate of $37.5 \%$, which pushed up the money supply by an average annual rate of $23.0 \%$ during the three years in question. Despite the difficulties caused by the war and the need to finance harvest surpluses, the Central Bank was able to hold down the growth of the money supply to a rate far below that of the increase in international reserves.

The Central Bank's policies during the war were just as efficient as its anti-cyclical measures of 1935-1939 but it was the latter which, because of their technical beauty, attracted international 
attention. In his well-known analysis of the international monetary situation between the two world wars, Ragnar Nurkse referred to Argentina's monetary policy in the following terms:

"Argentina provides the most striking example of the neutralization of cyclical phenomena of both types (economic booms and recessions) during the three years between 1936 and 1939. Here, once again, mid- 1937 was a critical period. The changes then occurring in the world market had a particularly strong effect on Argentina's balance of payments because they were reinforced by an inflow of external funds before this critical juncture and by an outflow of such funds after it, as well as by weather conditions which produced an exceptionally good harvest before and a very poor harvest immediately after this point in time. These events had surprisingly little effect on the domestic credit situation due to the quite notable policy of monetary 'isolationism' that was applied during both the economic boom and the depression. The inflow of foreign exchange in 1936 and in the early months of 1937 was sterilized, firstly, by the Central Bank's sale of securities and, after November 1936, by the transfer of treasury certificates and bills to the market for purchases of foreign exchange on behalf of the government... The toral amount of [foreign] exchange absorbed by these means reached a peak of over one billion pesos in June 1937, which were sold during the following 18 months. The proceeds from these sales were used to pay for the treasury bills and certificates which had been issued to finance them... Thanks to the neutralization policy, the monetary expansion observed in 19361937 was moderate in comparison to the rise in exports and the inflow of funds; analogously, the decline in domestic credit during 1937-1938 was slight in comparison to the turnabour in the balance of external payments." 14

\section{Model banking laws}

Argentina's experience served as an inspiration for Robert Triffin's work concerning the revision of the structure and functions of central

"Ragnar Nurkse, La experiencia montaria interndionsi, IMF/IDB/CEMLA, Mexico City, 1968, p. 90 . banks in developing countries, which was reflected in the laws of Paraguay, Guatemala, the Dominican Republic and Ecuador. These, in their turn, served in part as a model for the laws which created the central banks of Chile and Honduras and for the modifications made in the banking laws of E1 Salvador and Venezuela. The work of Raúl Prebisch can thus be said to have been the basis for the contemporary central banking system in Latin America.

The beauty of the theories underlying the new banking laws and the promise these laws held out for neutralizing the economic cycle sparked the enthusiasm of Latin American economists. As a result, we placed our faith in monetary and exchange policy as the key tool for solving many of our problems and concentrated our efforts on refining the techniques of monetary analysis and the central banks' instruments of control as much as possible. This was a time during which we spent long hours discussing how to compute the revaluation of reserves in the classification of the means of payment by origin and attempting to create controls of all sorts that would make central banks better able to offset external fluctuations.

Latin American economists' enthusiasm for the new banking laws and especially for their exchange provisions was not due so much to the contribution they might make to a more complete neutralization of the economic cycle as it was to the fact that they offered a possibility of speeding up industrialization by making it possible to continue investing and growing during cyclical downswings: when exports declined, we freed the exchange rate for luxury imports, restored our balances of payments to equilibrium and continued investing in industry and infrastructure. Our eagerness to apply the new monetary policy was due to the fact that it provided an indirect instrument for promoting industrialization. However, once we had found a more direct route to our goal (thanks in large part to Prebisch), it was then no longer necessary to take such a roundabout path, and we devoted our full attention to development theory and policy. Moreover, development policy could be applied in an anti-cyclical manner by intensifying the construction of infrastructure projects and the acquisition of external loans when exports were decreasing, thereby providing at least a partial 
substitute for monetary policy as a neutralizer of the economic cycle. The actual circumstances involved were yet another factor, since trade fluctuations were much less notable after the war than they had been before it, and there was thus much less need to apply an anti-cyclical monetary policy.

Latin American economists' enthusiasm for monetary policy reached its height shortly after 1945, attaining its maximum expression at the First Conference of Central Bank Technical Experts of the Americas, to which a number of references have been made. It rapidly waned during the 1950s as interest shifted to the theory and policy of economic development and to the scudy of the causes of inflation, which had already become a very serious problem in various Latin American countries before it made its appearance in the rest of the world. Partly because of this shift in interest and partly due to other causes, the rest of the tools which the new legislation made available to central banks were never used, either at the time of their creation or in subsequent years. In fact, during the past 40 years no central bank has applied an active anticyclical policy such as that implemented by Raúl Prebisch in Argentina in 1935-1943.

\section{Factors militating against the application of an anti-cyclical monetary policy in Latin America during the postwar period}

The loss of interest by Latin American economists in anti-cyclical monetary policy and the scant use made of this tool by financial authorities during the four decades that have passed since the end of the war appear to be due to a variety of reasons. The most important of these seem to be the following: a) the predominance of development policy; b) the possibility of applying development policy in an anti-cyclical fashion; c) the absence of sharp fluctuations in international trade; d) the fact that the new type of inflation that has emerged seems to be largely unaffected by credic restrictions, which have caused severe economic contractions; e) the impossibility of applying a consistent monetary policy in the presence of a combination of inflation and unemployment; $f$ ) the increase in interest rates in industrial countries; g) the tax-exempt status of foreign deposits in the United States; and $h$ ) the debt crisis.

As a result of the sharp inflationary surges observed in various Latin American countries around 1950, a great deal of importance was initially placed on monetary policy. However, this inflation proved to be highly resistant to monetary restrictions, which had a much greater effect on production than on prices; these restrictions therefore gave rise to a steep increase in unemployment, but prices continued rising in spite of this. Such restrictions thus produced a situation of "stagflation", with the economy suffering from both unemployment and inflation at the same time. Given this situation, which is entirely contrary to the teachings of economic theory, What monetary policy should be followed? Should a tight credit policy be continued in the hope that, after a sufficiently long period of time, prices will drop, or should the constraints on credic be lifted in order to stimulate production and employment? "Sragflation" has thus prevented the application of a consistent monetary policy, and it continues to do so today.

The above-mentioned factors which have discouraged or hampered the application of monetary policy have been compounded, more recently, by the rise in interest rates in the industrial countries, the tax exemption of foreign deposits in the United States, and the debt crisis. The first two of these factors have augmented the outflow of capital from Latin America, already greatly encouraged by exchange instability, and have created additional difficulties for monetary policy-makers by presenting them with the dilemma of whether to raise domestic interest rates, which would keep capital within the region but would also slow down the economy, or to lower them, which would stimulate the economy but would also intensify the outflow of capital from the region. The third factor, the debt crisis, has created extremely severe problems for monetary policy by siphoning off an enormous amount of resources.

\section{What lessons are to be learned from Prebisch's handling of monetary affairs?}

This brief examination of the difficulties in relation to monetary policy which have been encountered in the past 40 years might, at first 
glance, give the mistaken impression that Raúl Prebisch's admirable performance at the helm of the Central Bank of the Argentine Republic offers relatively few lessons that could be of use in resolving today's problems. What greater benefit could we hope to derive, however, from a study of his performance than to gain an understanding of the economic and financial changes that have occurred in Latin America and the world during those 40 years? What better way of grasping the essential importance which monetary policy still has for economic development and social well-being than to understand how the situation in which such policy is to be applied has changed?

An analysis of the eight factors listed above indicates that the teachings of Prebisch remain valid, because the first three factors are not obstacles as such but rather circumstantial factors which caused a higher priority to be placed on other policies, while the last five factors, although they do represent real obstacles, have their origin in international problems which, even though they have gone unresolved for a number of years, will, we should trust, be solved in the not too distant future. We can and should, therefore, re-examine the techniques used by Raúl Prebisch and use them to promote the region's economic development within a context of financial stability.

Two of the real obstacles have their roots in inflation, and their future significance will therefore depend on how much progress we make in our struggle to halt this process. In recent years this problem has grown worse as a result of the heavy blow dealt to the region by the debt crisis. Nonetheless, the better understanding that economists both in Latin America and elsewhere now have of the mechanisms of persistent inflation and of stagflation gives us reason to believe that not much more time will pass before we have practical and effective formulas for overcoming this critical problem. ${ }^{15}$ This optimism

\footnotetext{
1'In this connection, see Inflación, aceleración y contención, Pensamiento lacroamericuno, No. 9. Madrid, january.June 1986; Rudiger Durnbusch, Inflution and Indexation. Comments on Brazil, Institute for International Economics, Washington, D. C, 1985: and, by the author, Inflation. Exchange Rates and Stabilization. Es sayp in International Finance, Princeton University, 1986; and Michael Bruno and Jeffrey Sachs, ficonsmics of Worldurde Stugflution, Harvard Universicy Press, 1985.
}

does not, however, mean that we should desist in our efforts to fathom the remaining enigmas posed by inflation.

The next two obstacles to an effective application of monetary policy stem from the greater attractiveness for Latin American savers of the possibility of making deposits in industrial countries due to the increase in interest rates in these nations. Making such deposits in the United States is the most attractive option of all because there such deposits are tax free. Latin American savers thus have the choice of holding their liquid funds in securities denominated in weak and depreciating currencies and of paying taxes on the interest earned, or of acquiring securities denominated in dollars which are rising in value in terms of the national currency of the purchaser, provide returns at a relatively high rate of interest and are exempt from taxes. There can be little doubt as to which alternative they will choose! It is to be hoped, however, thar in the not too distant future the United States will levy a heavy tax on financial deposits made by residents of developing countries or, even better, offer to sign tax agreements with these countries whereby it would undertake to charge, on their behalf, the taxes they levy on foreign financial deposits by their residents. The transfers of capital now being made by poor countries to rich countries constiture a process which is so thoroughly illogical and so contrary to the most basic principles of equity that this hope ought not to be entirely illusory.

The last of the obstacles mentioned above, the debt crisis, concerned Prebisch during the final years of his life. Indeed, just five days before his death, he said "the present bilateral negotiations cannot drag on indefinitely because, so long as the region's economies are being drained in order to generate resources with which to pay the service on the debt, there will be no investment, either domestic or foreign, since capital is not invested in economies that are not growing or are declining and that are subject to increasing social pressures", 16 The debt crisis cannot be

"6Raúl Prebisch, Address delivered by Dr. Raúl Prebisch at the twenty-first session of ECLAC, ClPAL. Retieu', No. 29 (LC/G,1427), Santiago, August 1986. 
allowed to continue to hold back Latin American and world progress for much longer.

Once the obstacles which have stood in the way of an effective application of monetary pol- icy are overcome, as they will have to be in the fairly near future, Raúl Prebisch's teachings concerning monetary and banking affairs will once again come into their own. 